\title{
Pathological, microbiological and immunohistochemical characterization of avian colibacillosis in broiler chickens of Mozambique ${ }^{1}$
}

\author{
Paula Augusto Taunde ${ }^{2 *}$ (D), Matheus V. Bianchi ${ }^{2}$ (D), Velosa M. Mathai ${ }^{3}$, \\ Cintia De Lorenzo ${ }^{2}$, Benigna D.C.B. Gaspar ${ }^{4}$, Irisalda Maria S.M. Correia ${ }^{5}$, \\ Claudio João M. Laisse ${ }^{3}$ and David Driemeier ${ }^{2}$
}

\begin{abstract}
Taunde P.A., Bianchi M.V., Mathai V.M., De Lorenzo C., Gaspar B.D.C.B., Correia I.S.M., Laisse C.J.M. \& Driemeier D. 2021. Pathological, microbiological and immunohistochemical characterization of avian colibacillosis in broiler chickens of Mozambique. Pesquisa Veterinária Brasileira 41:e03831, 2021. Setor de Patologia Veterinária, Departamento de Patologia Clínica Veterinária, Faculdade de Veterinária, Universidade Federal do Rio Grande do Sul, Av. Bento Gonçalves 9090, Prédio 42505, Porto Alegre, RS 91540-000, Brazil. E-mail: paulataunde@gmail.com

Avian colibacillosis is an acute and globally occurring infectious disease of domestic and wild birds caused by Escherichia coli, and it is associated with considerable economic losses mainly due to the morbidity and mortality associated. The present study aimed to describe the pathological, bacteriological and immunohistochemical aspects of avian colibacillosis in broiler chickens of Mozambique. Forty-nine broiler chicken presented anorexia, decreased weight gain, ataxia, diarrhea, dyspnea, and death in a clinical course of 3-5 days. The birds were raised in five farms (small, medium and large farms) with manual and automatic breeding system, with flocks ranging from 100 to 20,000 birds. At the necropsy, all birds had poor body condition, and the pericardium and the Glisson's capsule of all avian exhibited different degrees of adherence often associated with severe fibrin deposition. The thoracic and abdominal air sacs were thickened and adhered to the costal wall. Mild, moderate or marked hepatomegaly associated with white pinpoint multifocal areas $(100 \%, 49 / 49)$ and mild to moderate splenomegaly in $75.5 \%(37 / 49)$ with a mottled surface were observed. The lungs and kidney were enlarged and reddish. Histologically, a multiorgan fibrinoheterophilic polyserositis was observed in $75.5 \%$ of the cases $(37 / 49)$, which were characterized by inflammatory infiltrates composed mainly of degenerative heterophils, macrophages and plasma cells, associated with fibrin deposits and intermixed by coccobacillary bacterial basophilic aggregates. These affected mainly the pericardium $(28.6 \%, 14 / 49)$, the pleura $(18.4 \%, 9 / 49)$, the Glisson's capsule $(10.2 \%, 5 / 49)$, the ventriculus $(10.2,5 / 33)$, and the proventriculus $(8.2 \%, 4 / 49)$ serosa. Multifocal to coalescing areas of coagulative necrosis associated with similar inflammatory cells were observed mainly in the spleen $(28.6 \%, 14 / 49)$, liver $(24.5 \%, 12 / 49)$, and intestines $(22.4 \%, 11 / 49)$. A similar infiltrate was also observed affecting the the lungs $(16.3 \%, 8 / 49)$, the kidney $(16.3 \%, 8 / 49)$ and the myocardium $(14.3 \%$, $7 / 49$ ). Isolation and identification of $E$. coli was obtained in 12 cases through bacterial culture. Some organs ( 2 cases of each farms) were selected and submitted to immunohistochemistry
\end{abstract}

\footnotetext{
${ }^{1}$ Received on January 8, 2021.

Accepted for publication on February 16, 2021.

${ }^{2}$ Setor de Patologia Veterinária, Faculdade de Veterinária, Universidade Federal do Rio Grande do Sul (UFRGS), Av. Bento Gonçalves 9090, Agronomia, Porto Alegre, RS 91540-000, Brazil. *Corresponding author: paulataunde@gmail.com

${ }^{3}$ Secção de Anatomia Patológica, Departamento de Para-Clínicas, Faculdade de Veterinária, Universidade Eduardo Mondlane (UEM), Av. de Moçambique Km 15, Maputo, Moçambique.
}

\footnotetext{
${ }^{4}$ Secção de Microbiologia, Departamento de Para-Clínicas, Faculdade de Veterinária, Universidade Eduardo Mondlane (UEM), Av. de Moçambique Km 15, Maputo, Moçambique.

${ }^{5}$ Departamento de Produção Animal, Faculdade de Veterinária, Universidade Eduardo Mondlane (UEM), Av. de Moçambique Km 15, Maputo, Moçambique.
} 
anti-E. coli, and a positive stain was observed in all tested cases in liver (3/3), heart (4/4), spleen (1/1), lungs (4/4), intestines (4/4), bursa of Fabricius (1/1), ventriculus (1/1), and proventriculus (1/1) tissue sections. These results demonstrate that $E$. coli was the cause of mortality in these birds. Therefore, biosecurity and management measures should be employed to prevent and control the disease occurrence in Mozambique's poultry farming.

INDEX TERMS: Pathology, microbiology, immunohistochemistry, colibacillosis, broiler chickens, Mozambique, avian diseases, infectious diseases, bacteria, Escherichia coli, Maputo.

RESUMO.- [Caracterização patológica, microbiológica e imuno-histoquímica de colibacilose em frangos de corte de Moçambique.] A colibacilose aviária é uma doença aguda de ocorrência mundial que acomete aves domésticas e silvestres, causada por Escherichia coli e resulta em perdas econômicas consideráveis devido à elevada morbidade e mortalidade das aves. 0 presente estudo teve o objetivo de descrever os aspectos patológicos, bacteriológicos e imuno-histoquímicos de colibacilose aviária em frangos de corte de Moçambique. Um total de 49 frangos de corte apresentaram anorexia, baixo ganho de peso, ataxia, diarreia, dispneia e morte em um curso clínico de 3 a 5 dias. As aves eram provenientes de 5 granjas (pequenas, média e grandes), com sistema de criação manual e automático, com rebanhos que variavam de $100 \mathrm{a} 20.000$ aves. À necropsia, todas as aves exibiam condição corporal ruim a caquética, além de pericárdio e cápsula de Glisson de todas aves $(100 \%$; $n=49)$ com diferentes graus de aderência e deposição de fibrina de forma difusa acentuada. Os sacos aéreos torácicos e abdominais estavam espessados e aderidos à parede costal. Foi observado ainda hepatomegalia discreta, moderada a severa frequentemente associada com áreas multifocais puntiformes brancacentas (100\%; 49/49), e esplenomegalia discreta a moderada, associado a áreas multifocais moteadas (75,5\%; 37/49). Os pulmões e rins estavam aumentados e com coloração avermelhada. Histologicamente, observou-se majoritariamente serosite fibrinoheterofílica em $75,5 \%$ dos casos (37/49), caracterizadas por infiltrado inflamatório composto por heterófilos degenerados, macrófagos, linfócitos e plasmócitos, com deposição de fibrina entremeada por uma miríade de estruturas bacterianas cocobacilares. Esta lesão foi observada principalmente em pericárdio $(28,6 \%$; 14/49), pleura (18,4\%; 9/49), cápsula de Glisson (10,2\%; 5/49), ventrículo $(10,2 ; 5 / 33)$ e em proventrículo $(8,2 \% ; 4 / 49)$. Áreas multifocais a coalescentes de necrose de coagulação associada a infiltrado inflamatório semelhante ao descrito foi observado principalmente no baço $(28,6 \% ; 14 / 49)$, fígado $(24.5 \%$; $12 / 49)$, e intestinos $(8,2 \% ; 4 / 49)$. Um infiltrado inflamatório semelhante também foi visualizado em pulmões (16,3\%; 8/49), rins (16,3\%; 8/49) e miocárdio (14,3\%; 7/49), Colônias puras de E. coli foram identificadas e isoladas em 12 casos. Alguns órgãos (2 de cada granja) foram submetidos ao exame imuno-histoquímico anti- $E$. coli e marcação positiva foi visualizada em todos casos testados, como em fígado (3/3), coração (4/4), baço (1/1), pulmão (4/4), intestinos (4/4), bursa de Fabricius (1/1), rim (1/1), ventrículo $(1 / 1)$ e proventrículo (1/1). Estes resultados demonstram que E. coli foi a causa de morte destas aves. Sendo assim, a adoção de boas medidas de biosseguridade e de manejo são indispensáveis para a prevenção e controle da ocorrência da doença nas granjas de frango de corte de Moçambique.

TERMOS DE INDEXAÇÃO: Patologia, microbiologia, imuno-histoquímica, colibacilose, frangos de corte, Moçambique, doenças de aves, doenças infecciosas, bactérias, Escherichia coli, Maputo.

\section{INTRODUCTION}

Colibacillosis is a bacterial infectious disease that affects domestic and wild birds causing considerable economic losses in industrial and subsistence poultry farms, mainly due to the higher morbidity and mortality, as well as due to the higher costs with medical treatments (Dziva \& Stevens 2008, SolàGinés et al. 2015). The disease is caused by Escherichia coli, a gram-negative, non-spore forming, mobile, cocobacillary bacteria (Barnes et al. 2008, Markey et al. 2013). Many virulence factors have been demonstrated to play a crucial role in the pathogenicity of the strain (Nakazato et al. 2009). In addition, E. coli is a commensal bacterium of the intestinal mucosa of birds (Giovanardi etal. 2005, Srinivasan et al. 2014, Guabiraba \& Schouler 2015). The presence of some predisposing factors, such as stress, poor immune status, coinfections (Dziva \& Stevens 2008, Oliveira et al. 2019), physiological factors, environmental factors, as well as nutritional factors (Barnes et al. 2008), are associated with clinical disease. The disease may occur causing a massive mortality of poultry of multiple ages (Srinivasan et al. 2014). The condition is worldwide distributed and constitutes one of the major challenges in industrial and subsistence poultry (Oliveira et al. 2019, Kim et al. 2020), mainly due to delayed development of affected birds, resulting in uneven batches (Ask et al. 2006), decreased egg production and condemnation of carcasses at the slaughter (Barnes et al. 2008, Al-Arfaj et al. 2016). Colibacillosis may present as a located or systemic condition (Cavero et al. 2009, Kabir 2010, Guabiraba \& Schouler 2015), with the main clinical signs characterized by polyserositis, coligranuloma, omphalitis, septicemia, enteritis, and salpingitis (Barnes et al. 2008, Kabir 2010). The diagnosis of the condition may be obtained by the association of the clinical and pathological features in addition to the isolation and identification of the etiological agent (Barnes et al. 2008, Abalaka et al. 2017).

Mozambique's poultry farming is an important economic activity that generates income and employment in that country (FAO 2013, De Oliveira et al. 2015, MA 2007). Moreover, colibacillosis constitutes one of the major challenges for poultry productivity, being one of the main conditions diagnosed in poultry farming in Mozambique (FAO 2013). Similarly, the condition has been previously described in Africa in poultry of Nigeria (Anyanwu et al. 2014, Abalaka et al. 2017), Zimbabwe (Mbanga \& Nyararai 2015), as well as in laying hens of Egypt (Wafaa \& Median 2011) and Senegal (Vounba et al. 2019). Despite the lack of reports of colibacillosis in Mozambique, the increased mortality, reduced productivity in poultry, as well as decreased egg production in laying hens constitute an important barrier for poultry industry of this country. Therefore, the aim of this study was to describe the pathological, bacteriological, and immunohistochemical (IHC) findings of colibacillosis in poultry of Mozambique. 


\section{MATERIALS AND METHODS}

Birds that died were submitted to necropsy, and multiple fragments of organs were collected, fixed in $10 \%$ neutral buffered formalin for 48 hours, routinely processed for histology, embedded in paraffin, cut at $3 \mu \mathrm{m}$ and stained by hematoxylin and eosin (HE). The birds that were severely autolyzed were discarded from this study. During the visits to the farms, information regarding the size of the batch, age of the birds, adopted handling, poultry bedding condition, hygienic conditions, ventilation status, as well as clinical status of the birds were obtained.

For isolation and identification of the agent, samples of the liver, spleen, heart and lungs from 12 birds from different farms were subjected to microbiological analysis. Since the gross pattern of lesions was similar between the farms, at least one sample of each farm was randomly selected for microbiological analysis. Therefore, bacterial culture was performed from samples of three birds from Farm A, three from Farm B, one from Farm C, two from Farm D and three Farm E. The samples were inoculated onto 5\% blood agar and MacConkey agar, incubated for 24 hours at $37^{\circ} \mathrm{C}$ and the obtained colonies were identified through the association of cultural, morphologic and biochemical characteristics according to Markey et al. (2013).

Diagnosis confirmation was obtained through the detection of Escherichia coli antigens within multiple organs by the immunohistochemical technique (IHC). For this, one case of each farm was randomly selected, making a total of 18 tissue fragments: liver, heart, intestines and lungs, spleen, bursa of Fabricius, ventriculus and proventriculus. Antigenic retrieval was obtained by heating the sections with citrate buffer ( $\mathrm{pH}$ 6.0) for $10 \mathrm{~min}$, and nonspecific reactions were blocked with $5 \%$ skinny milk for $15 \mathrm{~min}$ at room temperature. The slides were incubated overnight at room temperature with the primary polyclonal antibody anti-E. coli (obtained from rabbit, ViroStart, Portland, Maine, USA) at a dilution of 1:200. The amplification signal was achieved by the peroxidase-labeled antibody method (MACH 4, Universal HRP-Polymer, Biocare Medical, Pacheco, California, USA), and the reaction was revealed with the chromogen 3-amino-9-ethylcarbazole (AEC, Biocare Medical, Pacheco, California, USA). The slides were counterstained with Harris hematoxylin. As negative control, tissue sections of liver, lungs, heart and intestines were incubated with phosphate buffered solution (PBS) instead of the primary antibody, and as positive controls, tissue sections of intestine, liver, heart and lungs positive for $E$. coli infection were employed (De Lorenzo et al. 2018).

\section{RESULTS}

\section{Epidemiological findings and clinical signs}

From December 2018 to February 2019, five broiler chicken farms located at the Maputo and Matola cities, presented increased levels of mortality of the birds with a clinical presentation of weight loss. The farms were classified as small (C), medium (D and E) and large sizes (A and B), and housed, respectively 100-2,000 birds, 2,000 to 20,000 birds, and above 20,000 birds. All farms had conventional buildings, with some particular features among them. Farms $A$ and $B$ had a ventilation system with exhauster fans, roofs with internal isolation system, automatic feeders and nipple drinker's system. The bedding was composed by wood shavings and it was in a good conservation status; however, the hygienic status was poor. Farms C, D and E had manual creation systems, with manual feeders and drinkers, poor natural ventilation system based on handling side-curtains, the hygiene was poor with moist bedding in advanced state of decay, and sick birds were not segregated. In all farms, during the visit (from 9 a.m. to 16 p.m.) it was noted that all birds had only access to water, were deprived from food, and some of the birds tried to ingest the bedding. In addition, the batches were severely uneven, with small, medium and large birds. Besides that, some birds mainly in three farms presented clinical signs of ataxia, dyspnea, cough, sneezing, white to yellowish diarrhea, and cachexia, especially in small to medium size farms.

The chicks were acquired from local incubators and the feeding was composed of protein, carbohydrates, minerals and vitamins, besides commercially available probiotics. The production cycle of the broilers ranged from 28 to 40 days. All owners highlighted that appropriate sanitary breaks of eight to 15 days were conducted, in addition to routine vaccination for Newcastle disease, infectious bronchitis and infectious bursitis, following the manufacturer instructions and according to the national vaccination program of broiler chicken in Mozambique (Do Amaral \& Mlay 2012).

The clinical course varied according to the farms. Farm A housed 18,000 to 20,000 chicks per lot (one month). The birds from this study were 15 to 30 days-old broilers and during the cycle it was registered diarrhea, weight loss, and mortality since the first week of life. Farm B housed 20,000 chicks per day, and the main complaint was weight loss, anorexia, and mortality affecting all age ranges. The farm had its own incubator for the supply of chicks, but it had a poor hatching rate. Farm $\mathrm{C}$ was the smallest, located less than $5 \mathrm{~m}$ from the owner house, with a dog kennel closely and a capacity of 250-300 chicks per cycle. At this location, it was registered weight loss, diarrhea, loss of appetite, and mortality along all productive cycle. Farm D housed up to 5,000 birds per cycle, and presented recurrent cough unresponsive to antibiotic treatment, anorexia, dyspnea, diarrhea, weight loss, and mortality starting at the first week of life. Additionally, at the vicinities of the farm there were areas with cattle, goat and sheep production. Farm E housed 2,000 to 4,000 chicks, with birds presenting a clinical course of ataxia, cough, dyspnea, whitish diarrhea, weight loss, and anorexia. Similarly to Farm $\mathrm{D}$, this farm had at the vicinities areas of cattle, goat and laying hens production.

In all farms, antibiotic treatment was employed with oxytetracycline, streptomycin, erythromycin, and gentamycin, but there was no clinical improvement. The owners highlighted that antibiograms were not previously conducted.

The morbidity rate was high (not estimated) in all farms, while the mortality rate in all productive cycle ranged from $3.9 \%$ to $25.6 \%$. During the analyzed period, 15 to 400 birds died per cycle at these farms.

\section{Necropsy findings}

At the external exam, birds from Farms A, D and E had a poor to cachectic body condition when compared to birds from Farms B and C, which had a regular body condition. Table 1 presents the number of birds submitted to necropsy and its age range according to each farm. Birds from Farm D had also ocular seropurulent exudates and torticollis. The birds from Farm E had also ataxia, besides ocular discharge and were in a poor body condition. 
Table 1. Distribution of necropsied animals and age range according to each farm

\begin{tabular}{ccccc}
\hline Farm & Birds & Age range (days) & Necropsied birds & Conclusive cases \\
\hline A & 16 & 15 and 28 & 10 & 7 \\
B & 19 & 3,9 and 12 & 12 & 10 \\
C & 4 & 30 & 2 & 2 \\
D & 7 & 35 & 7 & 7 \\
E & 25 & 19 and 20 & 25 & 23 \\
Total & 71 & & 56 & 49
\end{tabular}

In a total, 71 birds were analyzed, of which 56 were submitted to necropsy and a conclusive diagnosis was obtained in 49 cases. The remaining birds were discarded due to severe autolysis. At the internal exam, distinct degrees of adherence and severe fibrin deposits were observed at the pericardium (75.5\%, 37/49) (Fig.1), at the Glisson's capsule (75.5\%, 37/49) (Fig.2), and at the lungs (61.2\%, 30/49) affecting mainly birds with an age range of 9 to 35 days. A variable hepatomegaly (mild, moderate and severe) was observed in all birds, frequently occurring in association to multifocal pinpoint whitish areas $(75.5 \%, 37 / 49)$ occasionally reddish $(24.5 \%, 12 / 49)$. The liver was yellowish, occasionally orange, in $10.2 \%$ of the cases (5/49). Mild to moderate splenomegaly, frequently with a mottled aspect, was observed in birds from all farms, with an exception to Farm D. The thoracic (anterior and posterior) and abdominal air sacs were thickened and adhered in all adult birds. In Farm D, there was only thickening of the thoracic air sacs. Birds from Farms A, B, C, and $\mathrm{E}$ had dark-reddish kidneys occasionally covered with fibrin deposits. Birds with diarrhea had a diffuse reddish intestinal mucosa with liquid dark-red to white contents in $8.2 \%$ of the cases $(4 / 49)$.

\section{Histopathology}

Microscopically, distinct degrees of fibrinoheterophilic serositis were observed mainly involving the pericardium, pleura, air sacs, ventricularand proventricular serosa. The lesion was characterized by a diffuse infiltrate of intact and degenerate heterophils, macrophages often in phagocytic activity, which were intermixed by marked fibrin deposits and a myriad of coccobacilli bacterial structures (Fig.3). A mononuclear infiltrate composed of macrophages, lymphocytes, and plasma cells was observed frequently at the periportal spaces of the liver (Fig.4), at the interstitial space of the kidney and the lungs, as well as in air sacs and myocardium. The liver also presented multifocal to coalescent coagulative necrosis $(24.5 \%, 15 / 49)$ and diffuse intracytoplasmic vacuolization of hepatocytes $(32.7 \%, 16 / 49)$. The spleen had, mostly in adult birds, fibrinoid necrosis of follicular germinal centers and splenic arterioles (30.6\%, 15/49) (Fig.5) and marked white pulp hyperplasia $28.6 \%(14 / 49)$ of the cases, respectively. A moderate enteritis with infiltrate of heterophils, lymphocytes, and plasma cells, often intermixed by multiple coccobacilli bacterial structures at the apical surface of the villi, was observed in $8.2 \%$ of the cases $(4 / 49)$. Circulatory changes characterized by fibrinoid necrosis of blood vessels, thrombosis, congestion and hemorrhages were noted in $63.3 \%$ of the cases $(31 / 49)$ and especially in the liver, lungs, spleen and kidneys. IHC exam anti-Escherichia coli revealed marked multifocal immunolabeling in all fragments analyzed for each farm (Fig.6).

\section{Bacteriology}

Gram-negative small rods were identified in all 12 samples analyzed, which represented all farms of this study. Based on the biochemical (IMViC: indole+/MR+/VP-/citrate-) and morphological features of the colonies, the isolates were classified as E. coli.

\section{DISCUSSION}

The diagnosis of avian colibacillosis in the present study was obtained through the association of the epidemiological, clinicalpathological, bacteriological, and immunohistochemical findings. Colibacillosis manifests mainly as a septicemic disease involving multiple organs (Dutta et al. 2013, Abalaka et al. 2017). In the present study, the extra-intestinal form was the most frequent and observed mainly in all farms (A, B, C and E). The distinct clinical picture and severity of lesions observed in these farms may be related to the different handlings, vaccination, and bird's nutrition, in addition to some environmental stressful factors (Khaton et al. 2008, Kabir 2010) and immune status (Kabir 2010, Dziva \& Stevens 2008). The association of different predisposing factors may result in distinct clinical pictures (Barnes et al. 2008, Abalaka et al. 2017), during the period in which the birds died (summer), the southern region of Mozambique registered high temperatures, varying from 36 to $42^{\circ} \mathrm{C}$ (INAM 2018). Environmental factors, such as extreme heat, high humidity and poor ventilation, constitutes major challenges in poultry industry world widely, both for industrial and subsistence systems, since it increases bird's susceptibility to diseases, especially with an infectious origin, such as colibacillosis (Chansiripornchai 2009, Casagrande et al. 2017). Escherichia coli is an avian commensal agent of the intestinal tract (Barnes et al. 2008, Srinivasan et al. 2014, Guabiraba \& Schouler 2015), and, despite several predisposing factors were identified (high temperatures, prolonged fasting, poor ventilation), (Giovanardi et al. 2005, Barnes et al. 2008). Since birds were submitted to prolonged fasting, it may have favored a pursuit for other alternative sources of food, such as bedding. This may have been the infection source, as the agent is frequently found and excreted in feces of both infected and asymptomatic carrier's (Chansiripornchai 2009, Guabiraba \& Schouler 2015). Additionally, it is believed that $10-15 \%$ of the birds in farms are asymptomatic carriers of pathogenic $E$. coli, and that, in the presence of stressful factors, these birds may develop disease and disseminate the agent throughout the farms (Anyanwu et al. 2014), these can still cause death of these birds and low productivity of the farms as observed in the present study.

E. coli infection may be contained by adopting good handling practices, appropriate vaccination and biosecurity measures (Guabiraba \& Schouler 2015). In Mozambique, the vaccination against colibacillosis in birds is still not adopted; nonetheless, control and prevention for infectious diseases, including colibacillosis, is obtained through biosecurity measures, which varies according to the farm, but is often poor. This contributes to the settlement of infectious diseases as colibacillosis, which was reported in this study both in large, medium and small farms. Still, colibacillosis outbreaks are also detected in countries that employ the vaccination against the 

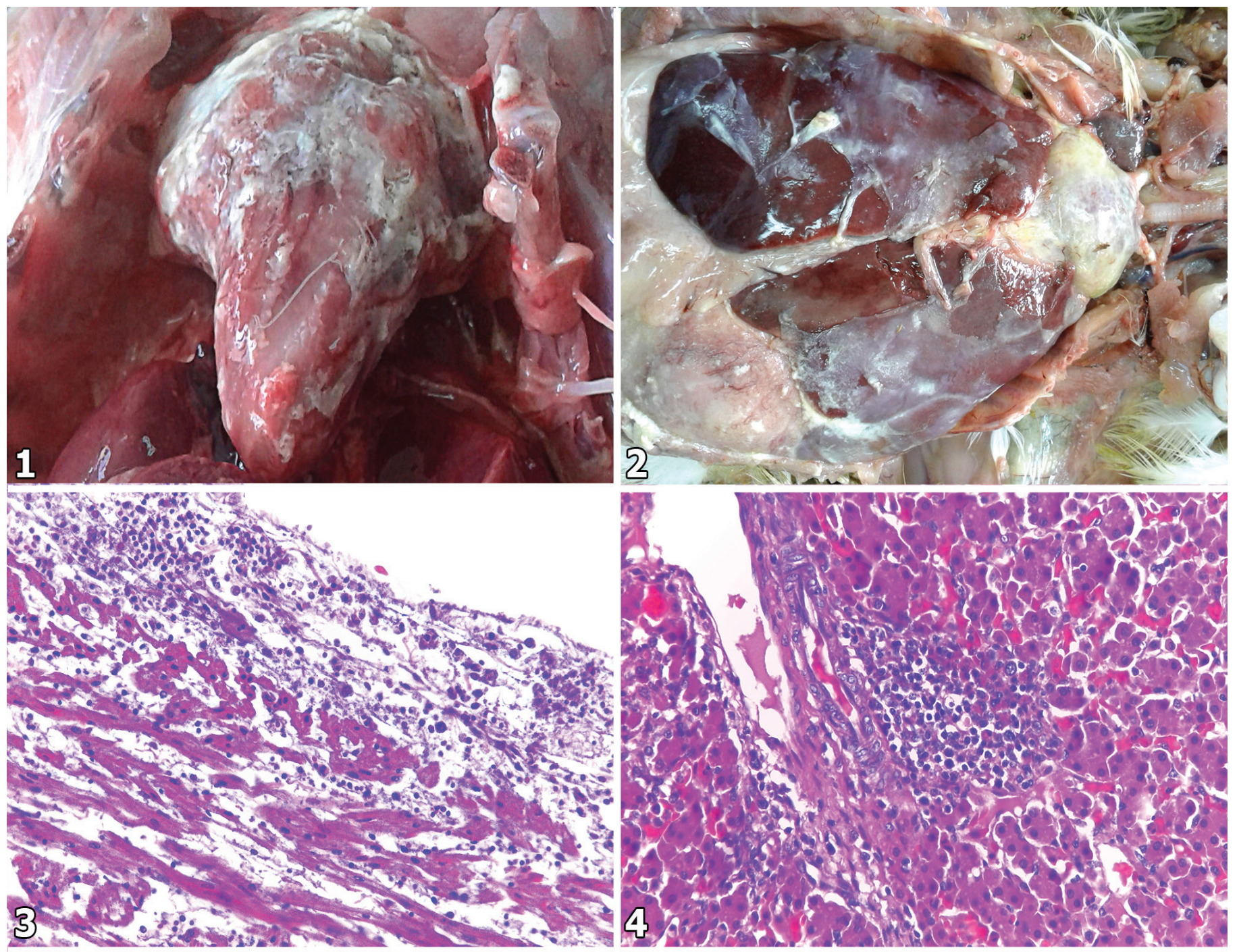

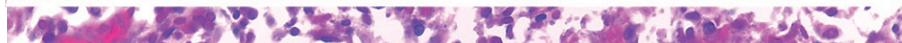
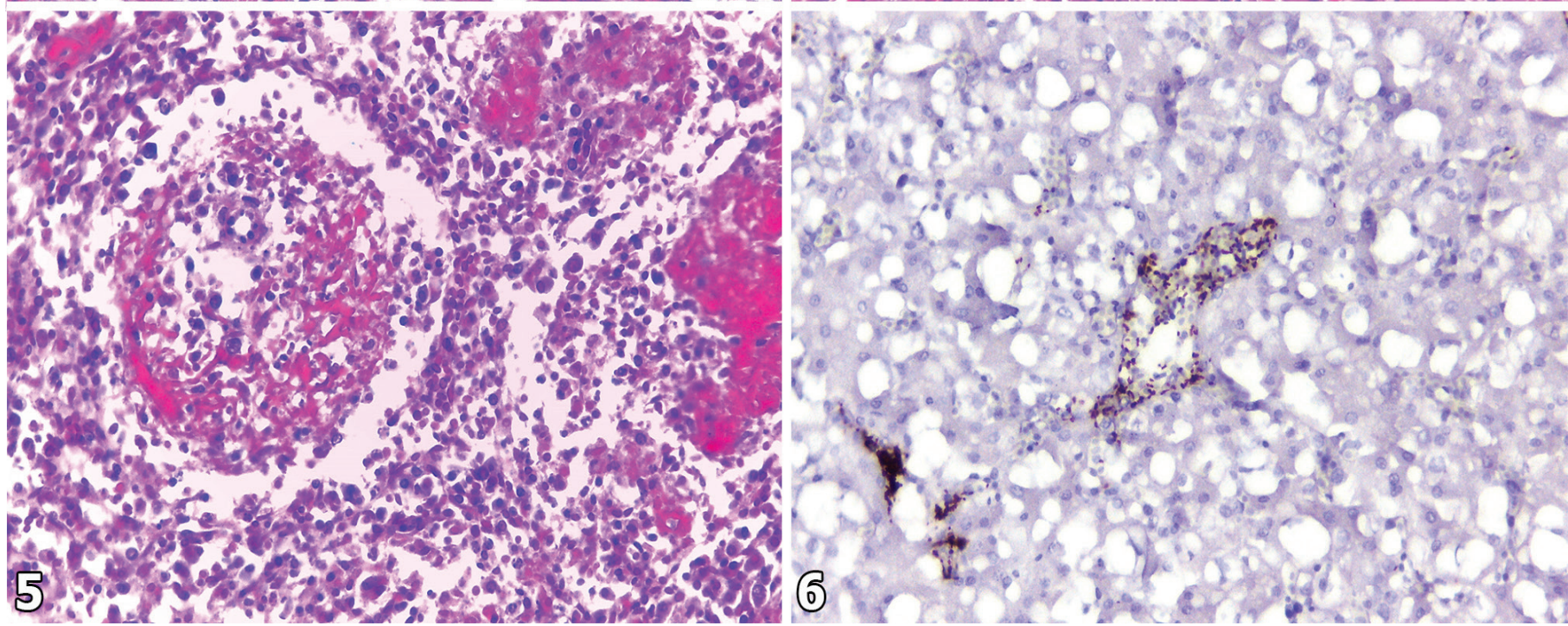

Fig.1-6. (1) Gross and microscopical findings of natural infection by Escherichia coli in poultry birds of Mozambique. (2) Heart. Areas of pericardial adherence characterized by severe fibrin deposits. (3) Liver. Enlarged, with multifocal areas covered by fibrin deposits. (4) Heart. Severe thickening of the pericardium with multiple intact and degenerate heterophils, macrophages, lymphocytes, and plasma cells intermixed by fibrin. HE, obj.40×. (5) Liver. Moderate infiltrate of macrophages, lymphocytes, and plasma cells predominantly at the periportal spaces. HE, obj.40×. (6) Spleen. Fibrinoid necrosis of follicular centers and blood vessels (splenic arteriole). HE, obj.40×. (7) Liver. Multifocal immunolabeling for E. coli in a periportal area and in sinusoids. IHC anti-E. coli, obj.40×. 
disease, such as in France, India, and Asiatic countries (Cavero et al. 2009, Guabiraba \& Schouler 2015, Abalaka et al. 2017). This suggests that the disease is an important cause of low productivity in poultry industry world widely (Cavero et al 2009, Dutta et al 2013), as observed in this study.

Colibacillosis affects avian with a wide age range (Kabir 2010, Srinivasan et al. 2014), and in young animals it usually occurs as omphalitis and yolk-sac infection (Abalaka et al. 2017). However, these lesions were not observed in the present study, although three and nine days-old chicks were also affected. The occurrence of the disease in young avian is related, not only to an elevated susceptibility at this age range (Barnes et al. 2008), but also to fecal infection of eggs, as in the present cases. Fecal contamination of eggs and posterior infection of chicks constitutes the major source of infection in these cases, with a challenge in controlling the condition (Barnes et al. 2008, Kabir 2010). This may result, in addition to embryonic death, in supplying infected chicks and, consequently, further spread of the agent, poor development and mortality of the birds due to the disease (Kabir 2010).

The presence of coinfections favors disease occurrence and determines the severity of the colibacillosis (Hossain et al. 2015, Casagrande et al. 2017, Kim et al. 2020). In Mozambique, despite vaccination efforts against the main viral conditions in poultry reports of Newcastle disease, Influenza infection, infectious bronchitis, pasteurellosis and salmonellosis outbreaks are frequent (FAO 2013). This study has not conducted any search for antibodies for these viral agents, yet, we cannot discard a coinfection with these agents in the present cases (Khaton et al. 2008, Hossain et al. 2015). Colibacillosis was the cause of death of all birds in the present study with gross and microscopical typical lesions, in spite of distinct lesion severity, which corroborates with the mortality caused by colibacillosis in broiler chicken (Abalaka et al. 2017) and in ranging from zero to six weeks-old (Hossain et al. 2015). Septicemic colibacillosis is the most frequent condition related to $E$. coli in birds, wherein clinical signs are characterized by depression, fever and high mortality (Kabir 2010), with fibrinoheterophilic polyserositis lesions similarly to the present study, especially in avian beyond 3 days of age. This corroborates the findings in broiler chickens (Abalaka et al. 2017), laying hens (Kabir 2010, Srinivasan et al. 2014), ducks (Barnes et al. 2008) and pigeons (Dutta et al. 2013). Additionally, lesions were observed mainly in the heart, liver, air sacs, pleura and at the serosa of the stomachs.

The inflammatory, necrotic lesions and the degenerative lesions observed in the of the present study, are commonly described in naturally occurring (Dutta et al. 2013, Srinivasan et al. 2014, Abalaka et al. 2017) and experimental cases of colibacillosis (Dwars et al. 2009, Wafaa \& Median 2011, Ozaki et al. 2018). Its occurrence is related mainly to vascular lesions caused by bacterial toxins (Wafaa \& Median 2011, Srinivasan et al. 2014). The difference at the presentation and severity of lesions in this study may be related to some factors such as handling, age, and feeding of the birds. In laying hens with colibacillosis, intestinal lesions are more prevalent (Khaton et al. 2008), but in our study intestinal involvement was less common than heart, liver, lungs and kidneys involvement. Nonetheless, our findings were similar to those obtained in broiler chickens up to two weeks-old (Wafaa \& Median 2011).
Pulmonary involvement is relatively common in E. coli infections, and it results from inhalation of bacteria disseminated through direct contact between sick or asymptomatic animals (Horn et al. 2012), as well as through high levels of ammonium or through coinfections by Mycoplasma spp., infectious bronchitis virus, pneumovirus, and Newcastle virus (Barnes et al. 2008, Dwars et al. 2009, Casagrande et al. 2017). These agents are related to necrotic lesions of the respiratory epithelium and later bacterial colonization, being bacterial inhalation one of the main forms of air sacs infection in susceptible birds independently of the age (Barnes et al. 2008). In the present study, the birds were housed in bedding in advanced state of decay, which allied to the poor ventilation system may have favored the high levels of ammonia with a subsequent development of colibacillosis (Barnes et al. 2008, Ewers et al. 2004).

The pattern of gross and microscopical lesions of colibacillosis varies individually and according to the virulence of the agent (Oliveira et al. 2019). Spleen is one the main organs affected in septicemic forms of colibacillosis, in which it can be grossly enlarged and mottled by pale areas, while microscopically it may exhibit necrosis of follicular centers, hemosiderosis, lymphoid depletion, besides white pulp hyperplasia (Barnes et al. 2008, Chansiripornchai 2009). These lesions were observed in 35 birds of the present study, and were predominantly characterized by areas with fibrinoid necrosis and lymphoid depletion in agreement with previous findings in broiler chicken of 15 to 34 days-old (Kabir et al. 2010, Abalaka et al. 2017).

Enteritis was observed in the present study and constitutes an unusual finding of avian colibacillosis, in spite of this lesion being commonly described in other mammals affected by $E$. coli, such as humans (Barnes et al. 2008), pigs (De Lorenzo et al. 2018), and cattle (Bashahun \& Amina 2017). The clinicpathological picture presented by the birds in this study is similar to that previously described in poultry chicken (Wafaa \& Median 2011), pigeons (Dutta et al. 2013) and piglets (De Lorenzo et al 2018). However, intestinal involvement of colibacillosis depends on some factors involved in the pathogenesis of the condition and varies according to each animal species (Guabiraba \& Schouler 2015, Bashahun \& Amina 2017).

Antibiotic therapy has been considered an important determinant for reducing economic losses by colibacillosis (Dou et al. 2016, Kim et al. 2020). To mitigate the severity of the clinical picture in these birds, all farms attempted an antibiotic treatment; however, clinical cases continued to occur, what suggests a possible bacterial resistance to the drugs employed. Although antibiograms for the isolates obtained were not conducted in this study, previous studies have described resistance of $E$. coli do a wide array of antibiotics (Dou et al. 2016, Borzi et al. 2018), including those used in the birds of the present study. Bacterial resistance constitutes a major problem in preventing and controlling infectious diseases world widely (Solà-Ginés et al. 2015, Oliveira et al. 2019, Kim et al. 2020). A common practice that may have favored bacterial resistance in these cases is the administration of subtherapeutic doses of antibiotics at the first week of life of birds, which is employed to reduce subsequent occurrence of infectious diseases. Uncontrolled use of antibiotics favors 
resistance development of bacteria and difficult the treatment of clinical cases (Solà-Ginés et al. 2015, Dou et al. 2016).

Bacterial isolation and proper morphological and/or biochemical identification constitute an important tool for the diagnosis of infectious diseases, such as colibacillosis (Barnes et al. 2008). Many factors may interfere with the quality of the test, such as the clinical picture, immune status, and antibiotic therapy (Khaton et al. 2008). Additionally, despite antibiotic therapy and factors related to the animals, such as distinct origins and distinct clinical pictures, isolation of pure colonies was obtained from samples of all analyzed farms.

Antigenic detection at immunohistochemical (IHC) analysis is an important tool for the diagnosis of infectious diseases in animals (Dwars et al. 2009). In this study, there was marked multifocal immunostaining in all analyzed tissues. Similarly, previous studies have reported marked multifocal immunostaining for $E$. coli in experimentally infected poultry (Dwars et al. 2009) and in naturally infected pigs (De Lorenzo et al. 2018). IHC was an important tool to confirm the diagnosis in the present study, since a wide array of clinical signs was observed in these birds, which should be differentiated from other diseases with an acute course, such as salmonellosis, pasteurellosis (Barnes et al. 2008, Bashahun \& Amina 2017), coccidiosis (Bashahun \& Amina 2017), enterococcosis, besides Klebsiella sp. infection (DebRoy et al. 2008). Differential diagnosis of salmonellosis was based on the absence of large intestine lesions, of coccidiosis due to the absence of parasite forms in the small intestine, of pasteurellosis due to the involvement of the spleen, as well as the isolation of $E$. coli.

\section{CONCLUSION}

Colibacillosis was the cause of death of these birds, and it is an important cause of low productivity of subsistence producers and poultry industry in Mozambique.

\footnotetext{
Acknowledgements.- We thank the "Conselho Nacional de Desenvolvimento Científico e Tecnológico" (CNPq), the "Coordenação de Aperfeiçoamento de Pessoal de Nível Superior" (CAPES), and the "Fundo Nacional de Investigação" (FNI - Projeto 16A, 9a Chamada) for supporting this study. To the lab technicians Leonardo Ngoca and Sercio Huo, from the "Secção de Anatomia Patológica", "Faculdade de Veterinária" of "Universidade Eduardo Mondlane" (UEM), and Salda Ndlalane and Reginaldo Guambe, from the "Secção de Microbiologia" of "Faculdade de Veterinária" of UEM for the technical support. To the owners and managers of the poultry, for making it possible the execution of this study. To the lab technician Bárbara Krebs from the "Setor de Patologia Veterinária" at the "Faculdade de Veterinária" of the "Universidade Federal do Rio Grande do Sul", for the help in performing some of the complementary tests.
}

Conflict of interest statement.- The authors have no competing interests.

\section{REFERENCES}

Abalaka S.E., Sani N.A., Idoko I.S., Tenuche O.Z., Oyelowo F.O., Ejeh S.A. \& Enem S.I. 2017. Pathological changes associated with an outbreak of colibacillosis in a commercial broiler flock. Sokoto J. Vet. Sci. 15(3):95-102. <https://dx.doi.org/10.4314/sokjvs.v15i3.14>

Al-Arfaj A.A., Ali M.S., Hessain A.M., Zakri A.M., Dawoud T.M., Al-Maary K.S. \& Moussa I.M. 2016. Phenotypic and genotypic analysis of pathogenic Escherichia coli virulence genes recovered from Riyadh. Saudi J. Biol. Sci. 23(6):713-717. <https://doi.org/10.1016/j.sjbs.2015.11.011> $<$ PMid:27872566>
Anyanwu M.U., Eezeasor C.K. \& Ngwu M.I. 2014. Case report of misdiagnosis of avian colibacillosis in laying birds. Anim. Res. Int. 11(2):1998-2003.

Ask B., van der Waaij E.H., Stegeman J.A. \& van Arendonk J.A.M. 2006. Genetic variation among broiler genotypes in susceptibility to colibacillosis. Poult. Sci. 85(3):415-421. <https://doi.org/10.1093/ps/85.3.415><PMid:16553269>

Barnes H.J., Nolan K.L. \& Vaillancourt J-P. 2008. Colibacillosis, p.619-716. In: Saif Y.M., Fadly A.M., Glisson J.R., McDougald L.R., Nolan L.K. \& Swayne D.E. (Eds), Disease of Poultry. 12th ed. Blackwell Publishing, New Jersey.

Bashahun G.M. \& Amina A. 2017. Colibacillosis in calves: a review of literature. J. Anim. Sci. Vet. Med. 2(3):62-71. <https://dx.doi.org/10.31248/ JASVM2017.041>

Borzi M.M., Cardozo M.V., Oliveira E.S., Pollo A.S., Guastalli E.A.L., Santos L.F. \& Ávila F.A. 2018. Characterization of avian pathogenic Escherichia coli isolated from free-range helmeted guineafowl. Braz. J. Microbiol. 49(Supl.1):107-112. <https://dx.doi.org/10.1016/j.bjm.2018.04.011>

Casagrande R.A., Machado G., Guerra P., Castro L.A., Spanamberg A., Silva S.C., Cardoso M.R.I. \& Driemeier D. 2017. Caracterização anatomopatológica e bacteriológica em frangos de corte condenados totalmente por colibacilose sob Serviço de Inspeção Federal. Pesq. Vet. Bras. 37(9):949-957. <https://dx.doi.org/10.1590/s0100-736x2017000900009>

Cavero D., Schmutz M., Philipp H-C. \& Preisinger R. 2009. Breeding to reduce susceptibility to Escherichia coli in layers. Poult. Sci. 88(10):2063-2068. <https://dx.doi.org/10.3382/ps.2009-00168> <PMid:19762857>

Chansiripornchai N. 2009. Comparative efficacy of enrofloxacin and oxytetracycline by different administration methods in broilers after experimental infection with avian pathogenic Escherichia coli. Thai J. Vet. Med. 39(3):231-236.

De Lorenzo C., De Andrade C.P., Machado V.S.L., Bianchi M.V., Rolim V.M., Cruz R.A.S. \& Driemeier D. 2018. Piglet colibacillosis diagnosis based on multiplex polymerase chain reaction and immunohistochemistry of paraffinembedded tissues. J. Vet. Sci. 19(1):27-33. <https://dx.doi.org/10.4142/ jvs.2018.19.1.27><PMid:28693311>

De Oliveira C.A.O., Pivoto D., Spanhol C.P. \& Corte V.F.D. 2015. Developments and competitiveness of Mozambican chicken meat industry. Revta Adm. IMED 5(2):205-216. <https://dx.doi.org/10.18256/2237-7956/raimed. v5n2p205-216>

DebRoy C., Roberts E., Jayarao B.M. \& Brooks J.W. 2008. Bronchopneumonia associated with extraintestinal pathogenic Escherichia coli in a horse. J. Vet. Diagn. Invest. 20(5):661-664.<https://dx.doi.org/10.1177/104063870802000524> $<$ PMid:18776106>

Do Amaral C.C. \& Mlay G. 2012. Análise de Custos e Rentabilidade da Produção Frangos no Sul de Moçambique - Estudo de caso na granja da Faculdade de Veterinária. Relatório preliminar de pesquisa no. 1. República de Moçambique. p.1-17.

Dou X., Gong J., Han X., Xu Mi., Shen H., Zhang D., Zhuang L., Liu J. \& Zou J. 2016. Characterization of avian pathogenic Escherichia coli isolated in eastern China. Gene 576(1 Pt 2):244-248. <https://dx.doi.org/10.1016/j. gene.2015.10.012><PMid:26475938>

Dutta P., Borah M.K., Sarmah R. \& Gangil R. 2013. Isolation, histopathology and antibiogram of Escherichia coli from pigeons (Columba livia). Vet. World 6(2):91-94. <https://dx.doi.org/10.5455/vetworld.2013.91-94>

Dwars R.M., Matthijs M.G.R., Daemen A.J.J.M., van Eck J.H.H., Vervelde L. \& Landman W.J.M. 2009. Progression of lesion in the respiratory tract of broilers after single infection with Escherichia coli compared to superinfection with $E$. coli after infection with infectious bronchitis virus. Vet. Immunol. Immunopathol. 127(1/2):65-75. <https://dx.doi. org/10.1016/j.vetimm.2008.09.019><PMid:19004507>

Dziva F. \& Stevens M.P. 2008. Colibacillosis in poultry: unravelling the molecular basis of virulence of avian pathogenic Escherichia coli in their natural hosts. Avian Pathol. 37(4):355-366. <https://dx.doi. org/10.1080/03079450802216652><PMid:18622850> 
Ewers C., Janben T., Kiebling S., Philipp H-C. \& Wieler L.H. 2004. Molecular epidemiology of avian pathogenic Escherichia coli (APEC) isolated from colisepticemia in poultry. Vet. Microbiol. 104(1/2):91-101.<https://dx.doi. org/10.1016/j.vetmic.2004.09.008> <PMid:15530743>

FAO 2013. Poultry Sector Mozambique. FAO Animal Production and Health Livestock Country Reviews No. 5, Food and Agriculture Organization of the United Nations, Mozambique.

Giovanardi D., Campagnari E., Ruffoni L.S., Pesente P., Ortali G. \& Furlattini V. 2005. Avian pathogenic Escherichia coli transmission from broiler breeders to their progeny in an integrated poultry production chain. Avian Pathol. 34(4):313-318. <https://dx.doi.org/10.1080/03079450500179046> $<$ PMid:16147567>

Guabiraba R. \& Schouler C. 2015. Avian colibacillosis: still many black holes. Microbiol. Let. 362(15):1-8. <https://dx.doi.org/10.1093/femsle/fnv118> <PMid:26204893>

Horn F., Corre A.M.R., Barbier N.L., Glodde S., Weyrauch K.D., Kaspers B., Driemeier D., Ewers C. \& Wieler L.H. 2012. Infections with avian pathogenic and fecal Escherichia coli strains display similar lung histopathology and macrophage apoptosis. PLoS One 7(7):e41031. <https://dx.doi.org/10.1371/ journal.pone.0041031 ><PMid:22848424>

Hossain M.B., Chakma S., Noman A. \& Van A. 2015. Prevalence of infectious and non-infectious diseases in different age groups of commercial layer chicken in Feni District, Bangladesh. J. Vet. Med. 26(1):35-38.

INAM 2018. Instituto Nacional de Meteorologia. Available at <http://opais. sapo.mz/inam-preve-vaga-de-calor-e-vento-com-rajadas-para-maputoe-gaza> Accessed on Aug. 8, 2019.

Kabir L.S.M. 2010. Avian colibacillosis and salmonellosis: a closer look at epidemiology, pathogenesis, diagnosis, control and public health concerns. Int. J. Environ. Res. Public Health 7(1):89-114.<https://dx.doi.org/10.3390/ ijerph7010089><PMid:20195435>

Khaton R., Haider M.G., Paul P.K., Das P.M. \& Hossain M.M. 2008. Colibacillosis in commercial chickens in Bangladesh. Bangladesh Vet. 25(1):17-24. <https://dx.doi.org/10.3329/bvet.v25i1.4614>

Kim Y.B., Yoon M.Y., Jong S.H., Seo K.W., Noh E.B., Son S.H. \& Lee Y.J. 2020. Molecular characterization of avian pathogenic Escherichia coli from broiler chickens with colibacillosis. Poult. Sci. 99(2):1088-1095. <https://dx.doi. org/10.1016/j.psj.2019.10.047><PMid:32029145>

MA 2007. Estratégia para o Desenvolvimento do Sub-setor Pecuário 20072016. Ministério de Agricultura, República de Moçambique.
Markey B., Leonardo F., Archambault M., Culinane A. \& Maguire D. 2013. Clinical Veterinary Microbiology. 2nd ed. Vol.2. Mosby Ltd., St Louis, p.249-254.

Mbanga J. \& Nyararai Y.O. 2015. Virulence gene profiles of avian pathogenic Escherichia coli isolated from chickens with colibacillosis in Bulawayo, Zimbabwe. Onderstepoort J. Vet. Res. 82(1):e1-e8. <https://dx.doi. org/10.4102/ojvr.v82i1.850><PMid:26017325>

Nakazato G., De Campos T.A., Stehling E.G., Brocchi M. \& Da Silveira W.D. 2009. Virulence factors of avian pathogenic Escherichia coli (APEC)1. Pesq. Vet. Bras. 29(7):479-486. <https://dx.doi.org/10.1590/S0100736X2009000700001>

Oliveira E.S., Cardoso M.V., Borzi M.M., Borges C.A., Guastalli E.A.L. \& Ávila F.A. 2019. Highly pathogenic and multidrug resistant avian pathogenic Escherichia Coli in free-range chickens from Brazil. Braz. J. Poult. Sci. 21(1):1-7. <https://dx.doi.org/10.1590/1806-9061-2018-0876>

Ozaki H., Yonehara K. \& Murase T. 2018. Virulence of Escherichia coli isolates obtained from layer chickens with colibacillosis associated with pericarditis, perihepatitis, and salpingitis in experimentally infected chicks and mbryonated eggs. Avian Dis. 62(2):233-236. <https://dx.doi. org/10.1637/11685-060717-ResNote.1><PMid:29944397>

Solà-Ginés M., Cameron-Veas K., Badiola I., Dolz R., Majó N., Dahbi N.G., Viso S., Mora A., Blanco J., Piedra-Carrasco N., González-López J.J. \& Migura-Garcia L. 2015. Diversity of multi-drug resistant avian pathogenic Escherichia coli (APEC) causing outbreaks of colibacillosis in broilers during 2012 in Spain. PLoS One 10(11):e0143191. <https://dx.doi.org/10.1371/journal. pone.0143191><PMid:26600205>

Srinivasan P., Balasubramaniam G.A., Murthy T.R.G.K. \& Balachandran P. 2014. Pathomorphological studies of polyserositis in commercial caged layer chicken. Asian Pac. J. Trop. Med. 7(Supl.1):S313-S320. <https://dx.doi. org/10.1016/S1995-7645(14)60252-2><PMid:25312143>

Vounba P., Arsenault J., Bada-Alambédji R. \& Fairbrother J.M. 2019. Prevalence of antimicrobial resistance and potential pathogenicity, and possible spread of third generation cephalosporin resistance, in Escherichia coli isolated from healthy chicken farms in the region of Dakar, Senegal. PLoS One 14(3):e0214304. <https://dx.doi.org/10.1371/journal.pone.0214304> <PMid:30913237>

Wafaa A., El-Ghany A. \& Madian K. 2011. Control of experimental colisepticaemia in broiler chickens using sarafloxacin. Life Sci. J. 8(3):318-328. 